\title{
Pathologies of Oligacanthorhynchus pardalis (Acanthocephala, Oligacanthorhynchidae) in Leopardus tigrinus (Carnivora, Felidae) in Southern Brazil
}

\author{
Patologias de Oligacanthorhynchus pardalis (Acanthocephala, Oligacanthorhynchidae) \\ em Leopardus tigrinus (Carnivora, Felidae) no sul do Brasil \\ Moisés Gallas ${ }^{1 *}$; Eliane Fraga da Silvera ${ }^{1}$
}

${ }^{1}$ Departamento de Biologia, Museu de Ciências Naturais, Universidade Luterana do Brasil - ULBRA, Canoas, RS, Brasil

Received September 9, 2011

Accepted November 23, 2011

\begin{abstract}
In Brazil, Oligacanthorhynchus pardalis (Westrumb, 1821) Schmidt, 1972 has been observed in five species of wild felines. In the present study, five roadkilled oncillas (Leopardus tigrinus Schreber, 1775) were collected in the State of Rio Grande do Sul, Brazil. Chronic lesions caused by O. pardalis were observed in the small intestine of one of the specimens. Histological examination identified a well-defined leukocyte infiltration and an area of collagenous fibrosis. Only males parasites $(\mathrm{n}=5)$ were found, with a prevalence of $20 \%$. The life cycle of Oligacanthorhynchus species is poorly known, although arthropods may be their intermediate hosts. The low prevalence encountered may be related to the small number of hosts examined, and the reduced ingestion of arthropods infected by larvae of $O$. pardalis. This is the first report of $O$. pardalis parasitizing L. tigrinus in the Brazilian state of Rio Grande do Sul.
\end{abstract}

Keywords: Oncilla, Oligacanthorhynchus, lesions, Neotropical Region.

\section{Resumo}

Para o Brasil, Oligacanthorhynchus pardalis (Westrumb, 1821) Schmidt, 1972 foi registrada em cinco espécies de felídeos silvestres. No presente estudo, cinco gatos-do-mato-pequenos (Leopardus tigrinus Schreber, 1775), vítimas de atropelamento, foram coletados no Estado do Rio Grande do Sul, Brasil. Lesões crônicas causadas por $O$. pardalis foram observadas no intestino delgado de um dos espécimes. Cortes histológicos permitiram a identificação de um infiltrado leucocitário bem definido e uma área de fibrose do colágeno. Somente machos $(\mathrm{n}=5)$ de $O$. pardalis foram encontrados, com prevalência de $20 \%$. O ciclo biológico das espécies de Oligacanthorhynchus é pouco conhecido, no entanto, artrópodes foram considerados como hospedeiros intermediários. A baixa prevalência encontrada pode estar relacionada ao número de hospedeiros examinados, bem como, com a ingestáo de poucos artrópodes infectados por larvas de $O$. pardalis. Este é o primeiro registro de $O$. pardalis parasitando L. tigrinus para o Rio Grande do Sul, Brasil.

Palavras-chave: Gato-do-mato-pequeno, Oligacanthorhynchus, lesões, Região Neotropical.

\section{Introduction}

Westrumb (1821) reviewed the species of the genus Echinorhynchus Zoega in Müller, 1776, and described the species Echinorhynchus pardalis, which was found parasitizing the intestine of Felis pardalis (= Leopardus pardalis Linnaeus, 1758). However, this author considered the species to be 'species dubiae'. Travassos (1917) considered $E$. pardalis to be the type species of the genus Pardalis, but subsequently (1918) transferred it to the genus Echinopardalis. Schmidt (1972) proposed a new classification, and considered the genus Echinopardalis to be a synonym of

\section{${ }^{*}$ Corresponding author: Moisés Gallas}

Departamento de Biologia, Museu de Ciências Naturais, Universidade Luterana do Brasil - ULBRA, Av. Farroupilha, 8001, São Luís, CEP 92425-900, Canoas, RS, Brasil

e-mail: mgallas24@yahoo.com.br
Oligacanthorhynchus Travassos, 1915. According to this, Ec. pardalis was assigned to the genus Oligacanthorhynchus, an arrangement supported by Amin (1985).

Travassos (1917) provided morphometric measurements on P. pardalis collected from different species of felines in southern and southeastern Brazil: Felis (Uncia) concolor (= Puma concolor Linnaeus, 1771), Felis (Leopardus) onça (= Panthera onca Linnaeus, 1758), Felis (Onçoides) tigrina (= Leopardus tigrinus Schreber, 1775), Felis (Onçoides) geoffroyi (= Leopardus geoffroyi d'Orbigny \& Gervais, 1844), Felis (Zibethailurus) chibigonzon (= L. pardalis), Felis (Leopardus) pardus (= L. pardalis) and Felis (Onçoides) mitis (= L. pardalis).

The oncilla (L. tigrinus), an endangered feline, occurs in all Brazilian biomes (SUNQUIST; SUNQUIST, 2002). The helminth 
fauna of this species is poorly known, although six parasite species (one cestode, three nematodes and two acanthocephalans) have been identified (DIESING, 1851 apud BELDOMENICO et al., 2005; TRAVASSOS, 1917; PETROCHENKO, 1971; HUNGRIA, 1978; SANTOS et al., 2009; GALLAS; SILVEIRA, 2011). The acanthocephalan species Oncicola campanulata (Diesing, 1851) Meyer, 1931, and $O$. pardalis were considered to be parasites of Felis tigrina (= L. tigrinus) by Petrochenko (1971).

Vieira et al. (2008) published a list of the helminth species of Brazilian carnivores. Muniz-Pereira et al. (2009) provided data on the parasites of endangered Brazilian vertebrates, but because they did not include the species reported by Petrochenko (1971), they reported only Trichuris sp. as a parasite of L. tigrinus.

Acanthocephalan species cause damage to their hosts in the area where the proboscis is attached, which may cause formation of nodules, granulomas and inflammations, and may predispose towards secondary infections (NICKOL, 1985; RICHARDSON; BARNAWELL, 1995; KENNEDY, 2006). Babero (1957) and Richardson and Barnawell (1995) described the lesions caused by Oligacanthorhynchus tortuosa (Leidy, 1850) Schmidt, 1972 in opossums in the United States, but no data are available on the lesions caused by other Oligacanthorhynchus species.

This study characterizes the lesions caused by $O$. pardalis through histological sections from a specimen of $L$. tigrinus obtained in the Brazilian state of Rio Grande do Sul.

\section{Materials and Methods}

Between 2008 and 2010, five roadkilled adult specimens of L. tigrinus were collected from highways in the Brazilian state of Rio Grande do Sul. These specimens were donated to the "Laboratório de Zoologia dos Invertebrados" at "Museu de Ciências Naturais da ULBRA", MCNU, for necropsy. The acanthocephalans encountered were processed according to the techniques described by Amato and Amato (2010). Ecological terms were utilized according to Bush et al. (1997). Morphometric measurements are presented as means with ranges and standard deviations and the number of specimens measured $(\mathrm{n})$ is given in parentheses. All measurements are given in micrometers, unless otherwise indicated.

Drawings were made with a drawing tube on a microscope. For histological processing, the sample was dehydrated in a graded series of xylene/ethanol before being embedded in a paraffin block. Histological sections of thickness $5 \mu \mathrm{m}$ were stained according to the method of Luna (1968). The parasite species was identified according to the classification of Amin (1985) and the host species, based on Wozencraft (2005). A representative specimen was deposited in the "Coleção Helmintológica do Instituto Oswaldo Cruz”, CHIOC, Rio de Janeiro, Brazil.

\section{Results}

Oligacanthorhynchus pardalis (Westrumb, 1821) Schmidt, 1972

Description based on 5 males. Acanthocephala, Archiacanthocephala, Oligacanthorhynchidae. Body 21-27 mm $(23.67 ; \pm 3.05 ; \mathrm{n}=3)$ long; $1.68-2.48 \mathrm{~mm}(2.09 ; \pm 0.29 ; \mathrm{n}=5)$ wide at testes level (Figures 1a, b and 2a). Proboscis 414-667 (559.67; $\pm 130.78 ; \mathrm{n}=3)$ long; 506-621 (575; $\pm 60.85 ; \mathrm{n}=3)$ wide with six rows of hooks (Figures $1 \mathrm{a}, \mathrm{b}$ and $2 \mathrm{a}$ ). The hooks are truncated at their tip and the last two rows of hooks lacks the anterior extension (Figure 1a). Hooks of first row measures 221.28-239.72 (230.5; $\pm 9.22 ; \mathrm{n}=5)$ in length, and 92.2-156.74 $(125.39 ; \pm 24.04 ; \mathrm{n}=5)$ in root; hooks of second row measures 221.28-267.38 (237.88; $\pm 18.9 ; \mathrm{n}=5)$ in length, and $119.86-156.74(136.46 ; \pm 13.68 ; n=5)$ in root; hooks of third row measures $221.28-239.72(228.66 ; \pm 7.71 ; n=5)$ in length, and 110.64-156.74 (125.39; $\pm 19.12 ; \mathrm{n}=5)$ in root; hooks of fourth row measures $156.74-202.84(193.62 ; \pm 20.62 ; n=5)$ in length, and 73.76-92.2 (79.29; $\pm 8.25 ; \mathrm{n}=5)$ in root; hooks of fifth row measures $119.86-129.08(125.39 ; \pm 5.05 ; n=5)$ in length, and $55.32-92.2(66.38 ; \pm 16.49 ; \mathrm{n}=5)$ in root; hooks of sixth row measures $82.98-101.42(94.04 ; \pm 7.71 ; n=5)$ in length, and 46.1-92.2 (70.07; $\pm 21.23 ; \mathrm{n}=5)$ in root (Figure 1a). Proboscis receptacle $736-1219(912.33 ; \pm 266.57 ; \mathrm{n}=3)$ long; 414-483 $(437 ; \pm 39.83 ; \mathrm{n}=3)$ wide (Figure $1 \mathrm{~b})$. Small neck and trunk without spines (Figure 1b). Lemnisci 10.95-11.54 mm (11.29; $\pm 0.30 ; \mathrm{n}=3)$ long, representing $47.7 \%$ of total body length (TBL) (Figure 1b). Testes elongated, near middle of body, anterior testis $2.3-3.35 \mathrm{~mm}$ $(2.65 ; \pm 0.42 ; \mathrm{n}=5)$ long, $0.60-1.21 \mathrm{~mm}(0.86 ; \pm 0.22 ; \mathrm{n}=5)$ wide; posterior testis $2.18-3.33 \mathrm{~mm}(2.71 ; \pm 0.44 ; \mathrm{n}=5)$ long, $0.80-1.15 \mathrm{~mm}(0.91 ; \pm 0.14 ; \mathrm{n}=5)$ wide (Figure $1 \mathrm{~b})$. Distance between the testes $92-575(262.2 ; \pm 197.58 ; n=5)$. There are four pairs of cement glands 4.14-7.82 mm $(5.48 ; \pm 1.73 ; \mathrm{n}=4)$ long (Figure 1b). Saefftigen's pouch 2.81-4.05 (3.31; $\pm 0.52 ; \mathrm{n}=5)$ long (Figure 1b). Copulatory bursa 2.78-4.14 (3.27; $\pm 0.62 ; \mathrm{n}=4)$ long, 0.94-1.40 (1.07; $\pm 0.21 ; \mathrm{n}=4)$ wide (Figure $1 \mathrm{~b})$.

\section{Taxonomic summary}

Synonyms: Echinorhynchus pardalis Westrumb, 1821; Pardalis pardalis (Westrumb, 1821) Travassos, 1917; Echinopardalis pardalis (Westrumb, 1821) Travassos, 1918.

Host: Leopardus tigrinus Schreber, 1775.

Site of infection: small intestine.

Locality: Dom Pedro de Alcântara, RS, Brazil.

Prevalence: $20 \%$.

Mean intensity of infection: 5 helminths/host.

Mean abundance of infection: 1 helminth/host.

Voucher specimen deposited: CHIOC No: 37807.

All five $O$. pardalis specimens were males. The measurements were similar to those reported by Travassos (1917), except for the width of the body, testes and cement glands, for which higher values were recorded in the present study.

One specimen was fixed in situ in the intestine, with free trunk and lesions of diameter $1 \mathrm{~mm}(\mathrm{n}=7)$, representing the proboscis attachments (Figure 2a). Macroscopic alterations of the serous layer consisting of nodules of 3.5 to $6.0 \mathrm{~mm}$ in diameter and 2 to $4 \mathrm{~mm}$ in height, corresponded to the sites at which the proboscis was attached to the lumen (Figure 2b).

Microscopic alterations were observed in the mucosa, submucosa, and muscularis layers, which were affected by the proboscis attachment. The analysis identified a leukocytic infiltration 

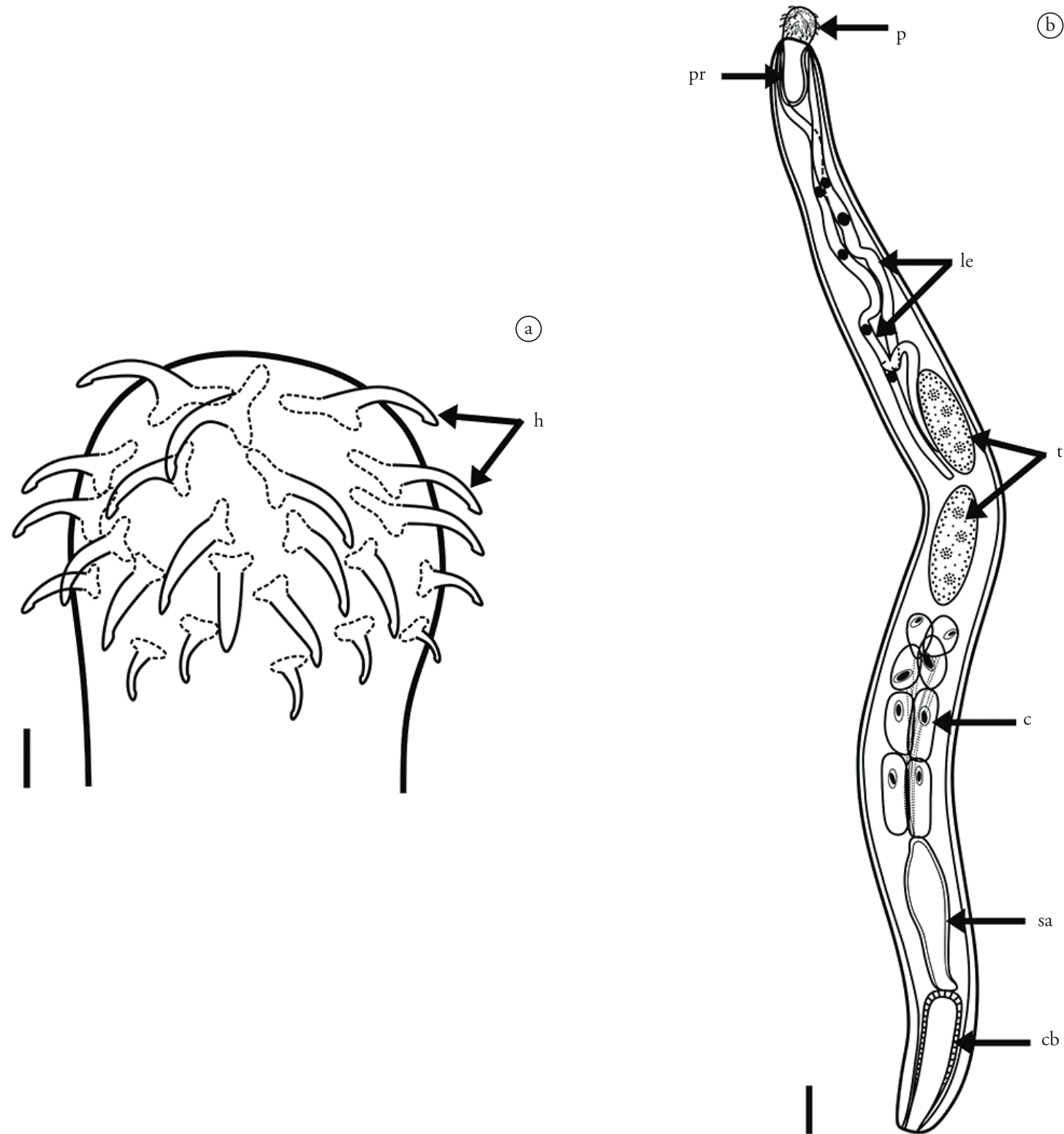

Figure 1. Incomplete diagrams of Oligacanthorhynchus pardalis: a) Proboscis with hooks (h), Scale bar = $100 \mu$ m; b) Total body with proboscis (p), proboscis receptacle (pr), lemnisci (le), testes (t), cement glands (c), Saefftigen's pouch (sa) and copulatory bursa (cb). Scale bar = $1 \mathrm{~mm}$.

between the submucosa and muscularis layers (Figure 2c). The area adjacent to this infiltration was characterized by coarse, fibrous collagen in a disorderly arrangement, with abundance of fibroblasts and fibrocytes (Figure 2d).

\section{Discussion}

In acanthocephalans, the sex ratio $(1: 1)$ is determined at fertilization (CROMPTON, 1985). Exclusive occurrence of male specimens may provoke competition among the $O$. pardalis males, thus resulting in changes to body and testis size (SASAL et al., 2000).

The lesions found in the present study are closely similar, in terms of nodule length and damage to the tissue layers, to those reported for O. tortuosa (BABERO, 1957; RICHARDSON;
BARNAWELL, 1995). Babero (1957) observed red nodules, which Richardson and Barnawell (1995) interpreted as the result from hemorrhaging caused by the attachment of the parasite. Absence of hemorrhaging and absence of polymorphonuclear leukocytes (PMN) are indicative of the chronic inflammation induced by $O$. pardalis, as reported in relation to $O$. torturosa by Richardson and Barnawell (1995).

The advanced state of putrefaction of the oncilla specimen impeded a more detailed analysis of the lesions. In particular, atrophic processes and necrotic abscesses, as reported by Babero (1957) and Richardson and Barnawell (1995), were not observed. The extensive fibrosis associated with leukocytic infiltration indicates that the parasites do not migrate after attachment (RICHARDSON; BARNAWELL, 1995). In the present study, 

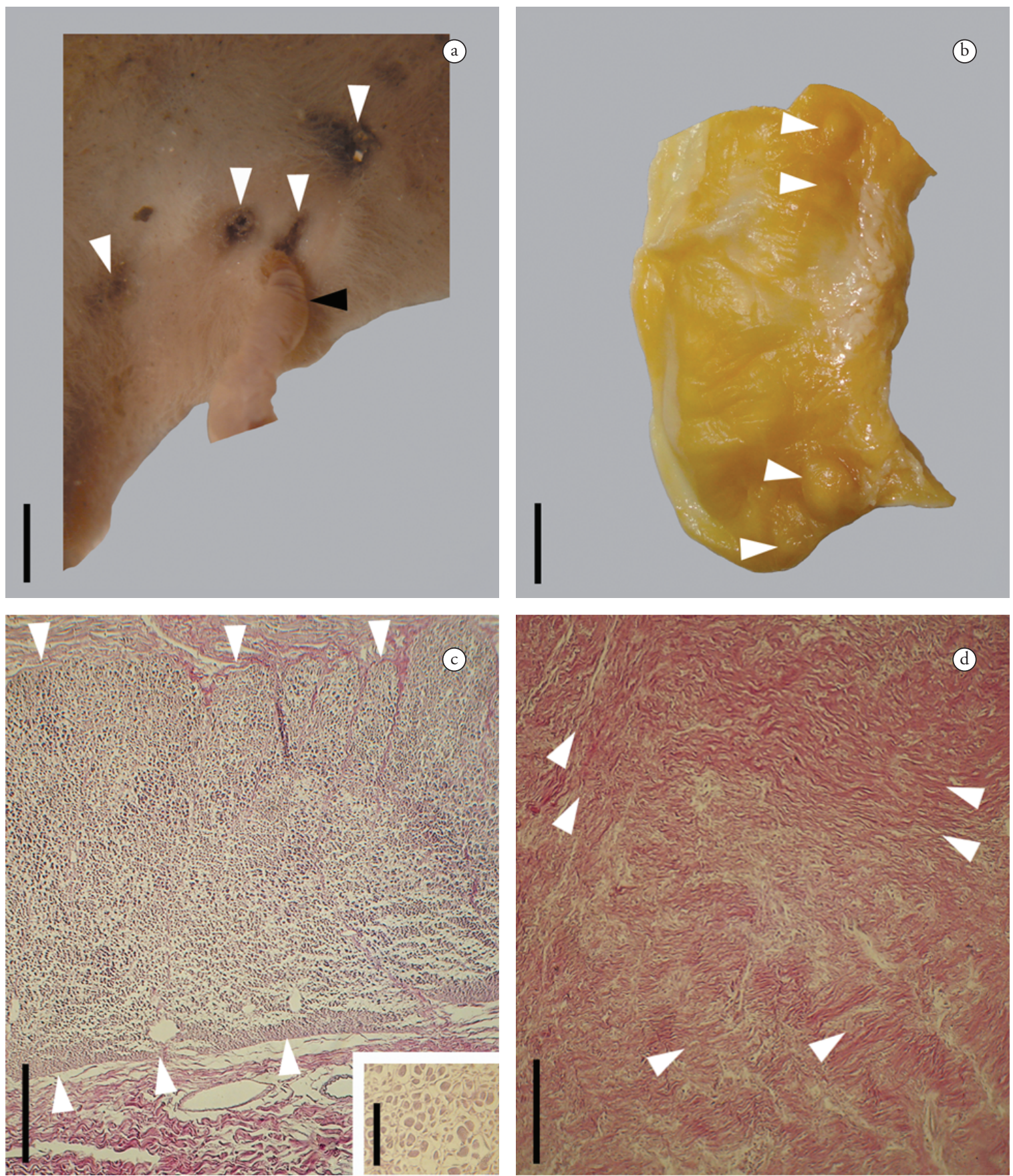

Figure 2. Photomicrographs of the lesions caused by Oligacanthorhynchus pardalis: a) Lumen layer showing one specimen attached (black arrowhead) and lesions (white arrowheads), Scale bar $=2 \mathrm{~mm}$; b) Serous layer showing nodules (white arrowheads), Scale bar $=9 \mathrm{~mm}$; c) Histological section showing the well-defined leukocyte infiltration (white arrowheads), Scale bar $=150 \mu \mathrm{m}$, and inset showing detail of the lymphocytes in the leukocyte infiltration, Scale bar $=60 \mu \mathrm{m} ; \mathrm{d}$ ) Fibrosis showing disorderly fibrous tissue (white arrowheads), Scale bar $=200 \mu \mathrm{m}$.

the presence of fibrosis indicates that the acanthocephalans did not migrate after attachment of their proboscises to the lumen of $L$. tigrinus. However, the number of lesions $(n=7)$, together with the number of $O$. pardalis specimens encountered $(n=5)$ also indicates that some specimens migrated before definitive attachment and formation of the fibrosis.

The first study on the life cycle of an Oligacanthorhynchus species was conducted by Richardson (2006). The diplopod Narceus americanus Palisot de Beauvois, 1817, has been identified as an intermediate host of $O$. tortuosa. Ingestion of rodents, lizards, birds, and arthropods by L. tigrinus has been documented by Sunquist and Sunquist (2002). The low infection rates found in the present study may be related to the small number of hosts analyzed and the low ingestion of arthropods infected with the larvae of $O$. pardalis.

Vieira et al. (2008) recorded $O$. pardalis as a parasite of only four feline species, L. pardalis, L. geoffroyi, P. onca, and Pu. concolor. However, their study overlooked Travassos (1917), who identified 
L. tigrinus from São Paulo, Brazil, as a definitive host of $O$. pardalis. The present study is the first record of $O$. pardalis parasitizing L. tigrinus in the Brazilian state of Rio Grande do Sul.

\section{Acknowledgements}

We are grateful to PROICT/ULBRA for the scholarship granted to the first author; to the biologist Felipe B. Peters (ULBRA) and Professor Eduardo Eizirik (PUCRS) for the donation of the specimens of L. tigrinus; Clarence and Rose (Laboratório de Histologia, ULBRA) for their help with histological procedures; Professor Lígia R. Ponts (ULBRA) for her assistance with characterization of the histological sections; Professor Dennis J. Richardson (Quinnipiac University) for his help with the bibliography; and Stephen Ferrari for revision of the English text.

\section{References}

Amato JFR, Amato SB. Técnicas gerais para coleta e preparação de helmintos endoparasitos de aves. In: Von Matter S, Straube FC, Accordi IA, Piacentini VQ, Cândido-Junior JF, organizadores. Ornitologia e Conservação: Ciência Aplicada, Técnicas de Pesquisa e Levantamento. Rio de Janeiro: Technical Books; 2010. p. 369-393.

Amin OM. Classification. In: Crompton DWT, Nickol BB, editors. Biology of the Acanthocephala. Cambridge: Cambridge University Press; 1985. p. 27-72.

Babero BB. Some helminths from Illinois opossums. J Parasitol 1957; 43(2): 232. http://dx.doi.org/10.2307/3274655

Beldomenico PM, Kinsella JM, Uhart MM, Gutierrez GL, Pereira J, Ferreyra HV. Helminths of Geoffroy's cat, Oncifelis geoffroyi (Carnivora, Felidae) from the Monte desert, central Argentina. Acta Parasitol 2005; 50(3): 263-266.

Bush AO, Lafferty KD, Lotz JM, Shostak AW. Parasitology meets ecology on its own terms: Margolis et al. revisited. J Parasitol 1997; 83(4): 575-583. PMid:9267395. http://dx.doi.org/10.2307/3284227

Crompton DWT. Reproduction. In: Crompton DWT, Nickol BB, editors. Biology of the Acanthocephala. Cambridge: Cambridge University Press; 1985. p. 213-271.

Gallas M, Silveira EF. Mesocestoides sp. (Eucestoda, Mesocestoididae) parasitizing four species of wild felines in Southern Brazil. Rev Bras Parasitol Vet 2011; 20(2): 168-170. http://dx.doi.org/10.1590/S198429612011000200014

Hungría CD. Helmintos parásitos de vertebrados en el estado Zulia (Venezuela) algunas especies nuevas para Venezuela. Vet Trop 1978; 3: 15-37.

Kennedy CR. Ecology of the Acanthocephala. Cambridge: Cambridge University Press;2006. 249 p. http://dx.doi.org/10.1017/ CBO9780511541902
Luna LG. Manual of Histologic Staining Methods of the Armed Forces Institute of Pathology. New York: McGraw-Hill; 1968. 258 p.

Muniz-Pereira LC, Vieira FM, Luque JL. Checklist of helminth parasites of threatened vertebrate species from Brazil. Zootaxa 2009: 2123: 1-45.

Nickol BB. Epizootiology. In: Crompton DWT, Nickol BB, editors. Biology of the Acanthocephala. Cambridge: Cambridge University Press; 1985. p. 307-346.

Petrochenko VI. Acanthocephala of domestic and wild animals. Jerusalém: Israel Program for Scientific Translations; 1971. v. 2, 478 p.

Richardson DJ, Barnawell EB. Histopathology of Oligacanthorhynchus tortuosa (Oligacanthorhynchidae) Infection in the Virginia Opossum (Didelphis virginiana). J Helminthol Soc Wash 1995; 62(2): 253-256.

Richardson DJ. Life Cycle of Oligacanthorhynchus tortuosa (Oligacanthorhynchidae), an Acanthocephalan of the Virginia Opossum (Didelphis virginiana). Comparative Parasitol 2006; 73(1): 1-6. http:// dx.doi.org/10.1654/4207.1

Santos KR, Faciulli P, Paparotto T, Takahira RK, Lopes RS, Silva RJ. First report of Strongyloides sp. (Nematoda, Strongyloididae) in Leopardus tigrinus (Carnivora: Felidae) in the municipality of Botucatu, State of Sáo Paulo, Brazil. Rev Bras Parasitol Vet 2009; 18(S1): 77-79. http://dx.doi. org/10.4322/rbpv.018e1016

Sasal P, Jobet E, Faliex E, Morand S. Sexual competition in an acanthocephalan parasite of fish. Parasitology 2000; 120: 68-69. http:// dx.doi.org/10.1017/S0031182099005272

Schmidt GD. Revision of the class Archiacanthocephala Meyer, 1931 (Phylum Acanthocephala), with emphasis on Oligacanthorhynchidae Southwell et Macfie, 1925. J Parasitol 1972; 58(2): 290-297. PMid:5022866. http://dx.doi.org/10.2307/3278091

Sunquist ME, Sunquist F. Wild cats of the world. Chicago: The University of Chicago Press; 2002. 452 p.

Travassos L. Contribuiçôes para o conhecimento da fauna helmintolojica brazileira. Mem Inst Oswaldo Cruz 1917; 9(1): 5-62. http://dx.doi. org/10.1590/S0074-02761917000100001

Travassos L. Helminthes parasitos de animaes domésticos. I. Rev Vet Zootec 1918; 8: 3-15.

Vieira FM, Luque JL, Muniz-Pereira LC. Checklist of helminth parasites in wild carnivore mammals from Brazil. Zootaxa 2008; 1721: 1-23.

Westrumb AHL. De Helminthibus acanthocephalis; commentatio historicoanatomica. Hanoverae Helwing; 1821.85 p. Adnexo recensu animalium, in Museo Vindobonensi circa helminthes dissectorum, et singularum speciocrum harum in illis repertarum. [cited 2010 Nov.]. Available from: http://www.archive.org/details/dehelminthibusac00west.

Wozencraft WC. Order Carnivora. In: Wilson DE, Reeder DM, editors. Mammal Species of the World: A Taxonomic and Geographic Reference. Baltimore: Johns Hopkins University Press; 2005. p. 532-628. 